\title{
FKBP1A wt Allele
}

National Cancer Institute

\section{Source}

National Cancer Institute. FKBP1A wt Allele. NCI Thesaurus. Code C102484.

Human FKBP1A wild-type allele is located in the vicinity of 20p13 and is approximately 24 $\mathrm{kb}$ in length. This allele, which encodes peptidyl-prolyl cis-trans isomerase FKBP1A protein, plays a role in the regulation of both signal transduction and protein folding. 